

\section{Sumário}

A DISCRIMINAÇÃo RACIAL NO BRASIL E A ASCENSÃo DO POVO NEGRO: UM OLHAR A PARTIR DOS PRINCÍPIOS CONSTITUCIONAIS NA LUTA PELA CIDADANIA INCLUSIVA

Bruno Mello Correa de Barros e Rita Mara Albrecht

As MULHERES NO CONTEXTO DA SOCIEDADE DE CLASSES E SUA PARTICIPAÇÃO POLÍTICA NO PROCESSO LEGISLATIVO E EXECUTIVO DO BRASIL: RESTRIÇÕES E DESAFIOS

Rafael Bueno da Rosa Moreira e Marli Marlene Morais da Costa

FACTORES ASOCIADOS A LA VIOLENCIA DE GÉNERo EN PAREJAS ADOLESCENTES

Maria del Carmen Monreal Gimeno

Os IMPACTOS DAS TECNOLOGIAS DA INFORMAÇÃO NO FLUXO DE PESSOAS: VIOLAÇÕES DA LIBERDADE EM UM MUNDO SECURITIZADO

Elias Jacob de Menezes Neto, Jose Luis Bolzan de Morais e Victoria Layze Silva Fausto

El DELITO DE ENALTECIMIENTO TERRORISTA. ¿INSTRUMENTO DE LUCHA CONTRA EL PELIGROSO DISCURSO DEL ODIO TERRORISTA O MECANISMO REPRESOR DE REPUDIABLES MENSAJES DE RAPEROS, TWITTEROS Y TITIRITEROS?

Alfonso Galán Muñoz

As POLÍtiCAS PÚBLICAS E A PROMOÇão DA DIGNIDADE: UMA ABORDAGEM NORTEADA PELAS CApacidades (CAPABIlities APproach) propostas por Martha Nussbaum

Anna Paula Bagetti Zeifert e Janaína Machado Sturza

A INFLUÊNCIA DA MÍdia PARA O CONSUMO DE TABACO

Luís Renato Vedovato e Maria Carolina Gervásio Angelini

¿SON PARTE DEL BLOQUE DE CONSTITUCIONALIDAD LOS PRINCIPALES TRATADOS internacionales de derechos humanos de la ONU en Chile? Del texto positivo a la APLICACIÓN EN TRIBUNALES DE JUSTICIA Juan Pablo Díaz Fuenzalida

Potestad calificadora del Conservador de Bienes Raíces y Procedimiento Registral ....173 Sebastián Bozzo Hauri e Gonzalo Ruz Lartiga

DESARTICULAÇÃo INTERFEDERATIVA E CONCESSÃo DOS BENEFÍCIOS DE PRESTAÇÃo CONTINUADA (BPC) 
Aprendizagem Profissional e o poder público municipal: proposta de maior eficácia À POLÍTICA PÚBLICA

José Rodrigo Paprotzki Veloso

Direito A Conciliação Entre Trabalho E Família................................................229

Edilton Meireles de Oliveira Santos

Trabajo y diversidad funcional. La situación EN EL ORdenamiento JuRídico español 245 María Esther Carrizosa Prieto

Custos de TransaÇão como uma METAPolítica pública .........................................2276

João Luis Nogueira Matias e Ricardo José Brito Bastos Aguiar de Arruda

REVISITANDO O CONCEITO DE SERVIÇO PÚBLICO

Andre Luiz Dos Santos Nakamura

O Brasil FACE AOS NOVOS PADRÕES DE COMÉRCIO E INVESTIMENTO DOS ACORDOS INTERNACIONAIS

Michelle Sanchez Badin, Fabio Costa Morosini e David M. Trubek

Os contratos comerciais na Declaração dos Direitos de Liberdade Econômica (MP 881/19).

André Lipp Pinto Basto Lupi

O MARCO LEGAL DA INOVAÇÃO E O AUMENTO DA INTERAÇÃO ENTRE UNIVERSIDADE E EMPRESA: CONTRIBUIÇÕES PARA A CONSOLIDAÇÃO DO DIREITO FUNDAMENTAL AO DESENVOLVIMENTO ....352 Thiago Paluma e Eline Débora Teixeira

RELICITAÇÃo DAS CONCESSÕES DE GERAÇÃo DE ENERGIA ELÉTRICA E A REVERSÃo DE BENS....372 Patrícia Regina Pinheiro Sampaio e Sergio Guerra

FinANCIAMENTO TRANSGERACIONAL DA INFRAESTRUTURA VERDE FLORESTAL: O SISTEMA DE PAGAMENTO POR SERVIÇOS AMBIENTAIS COMO INSTRUMENTO DE GESTÃO DE RISCOS NA SOCIEDADE CONTEMPORÂNEA...................................................................................................390

Délton Winter de Carvalho e Kelly de Souza Barbosa

Mediação como Política Pública para Tratamento de Conflitos Consumeristas ..... 415 Fernanda Sartor Meinero e Fernando Pedro Meinero

A ParticipaÇão do AMICUS CURIAE EM DECISÕES JUdiCIAIS E SUA CONSEQUENTE CONTRIBUiÇÃo para efetivação de Políticas Públicas .429

Viviane Nobre Santana 
A ISONOMIA TRIBUTÁRIA COMO LIMITE À TRIBUTAÇÃo E À CONCESSÃO DE ISENÇÕES FISCAIS, E A INEFETIVIDADE DO CONTROLE JURISDICIONAL DESSAS ISENÇÕES..................................450

Paulo Alves da Silva Paiva e Alexandre Augusto Batista de Lima

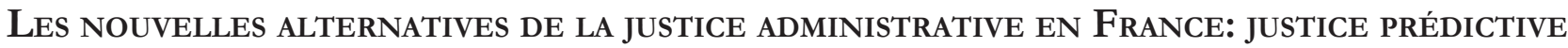
ET JUSTICE AMIABLE

Marie-Odile Diemer

O ESTADO DA LUXÚRIA: A PARÁBOLA DO BMW E A REAL DIMENSÃo DO DEBATE SOBRE A RESERVA DO POSSÍVEL: ESCASSEZ DE RECURSOS OU ORDENAÇÃo DE PRIORIDADES?................................484 Assis José Couto do Nascimento

O PODER CONSTITUINTE

José Levi Mello do Amaral Júnior

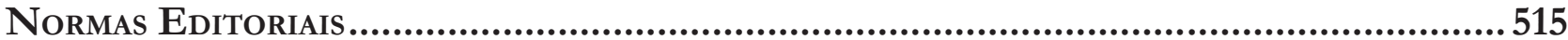

Envio dos trabalhos: 


\title{
O estado da luxúria: a parábola do BMW e a real dimensão do debate sobre a reserva do possível: escassez de recursos ou ordenação de prioridades?*
}

\section{The state of lust: the tale of BMW and the real dimension of the debate about the Boundaries of the achievable: is it scarce resources or priorities?}

Assis José Couto do Nascimento**

\section{Resumo}

Com base em exemplos específicos da gestão financeira e orçamentária brasileira, e na premissa de que tais exemplos representam uma realidade generalizável, este artigo formula a alegoria do BMW — uma situação teórica em que despesas desnecessárias e/ou equivocadas são utilizadas como fundamento para o argumento judicial da reserva do possível. Discorre, ainda, sobre uma possível deficiência na fundamentação das decisões judiciais que se utilizam do referido argumento.

Palavras-chave: Orçamento. Constituição. Reserva do Possível. Judicialização de Políticas Públicas. Gestão Pública.

\begin{abstract}
From specific examples relating to the Brazilian financial and budget management, and under the premise that such examples represent a generalizable reality, this article puts forward the BMW allegory - a theoretical situation where unnecessary and / or misguided expenses are used as a foundation for the judicial argument of the Boundaries of the possible achievable - also talking about a possible deficiency in the grounds of the judicial decisions using the above argument.
\end{abstract}

Keywords: Budget. Constitution. Boundaries of the possible achievable. Judicialization of Public Policies. Public Management.

* Recebido em 07/01/2019 Aprovado em 23/02/2019

** Mestre em Direito Constitucional pelo Instituto Brasiliense de Direito Público (2017). Professor no curso de Graduação em Direito do Instituto de Ensino Superior Planalto. Advogado. Email: ajn1974@gmail.com

\section{Introdução}

Ao que parece, o Estado brasileiro, em relação a seus credores, comporta-se de forma peculiar e que pode ser descrita pela seguinte metáfora: "não posso pagar o que devo, pois o cumprimento das minhas obrigações impedir-me-ia de comprar e manter meu BMW'. A metáfora é deliberadamente provocativa para 
insinuar que o Estado brasileiro seria pouco criterioso em relação a suas finanças, e que essa prodigalidade teria impacto direto e imediato na função estatal primeira de promover o bem comum. Paralelamente, nos estados constitucionais contemporâneos, está pacificado que essa função estatal fundamental é exteriorizada, em âmbito normativo, pelos direitos sociais inscritos na Constituição Federal, sendo passível de tutela na via judicial.

Surge, então, a necessidade de melhor compreender a questão orçamentária no setor público, no sentido de fundamentar adequadamente o debate que decorre das pretensões subjetivas judicializadas em face dos direitos socioconstitucionais, abstratamente considerados. Ora, com base nas lógicas que envolvem o agora denominado argumento orçamentário, o Judiciário não apenas deve decidir casos concretos que envolvem prestações estatais mas também precisa formatar uma jurisprudência que sirva de orientação-mestre para os atores sociais, e tal questão é especialmente sensível no espectro da jurisprudência do Supremo Tribunal Federal.

Em termos metodológicos, o objeto deste estudo circunscreve a relação binária (expectativas versus possibilidades) que exsurge dos debates judiciais sobre o orçamento público, analisando alguns aspectos da relação verificada entre as promessas constitucionais positivadas e as possibilidades reais de cumprimento daquelas promessas. De forma mais específica, trata-se de refletir sobre os dois vetores do argumento orçamentário: de um lado, se coloca o critério da reserva do possivel, argumento estruturado na ideia de que há um limite material para o atendimento de pretensões subjetivas e cuja aferição dar-se-ia por um critério de razoabilidade; por via diversa, há o argumento de que não é adequado frustrar a concretização de direitos constitucionais com base em uma certa interpretação da tecnocracia orçamentário-financeira.

Lembrando da hipótese deste trabalho, aquele suposto traço de prodigalidade que seria constatável na gestão dos recursos públicos, denota-se a pergunta representativa do problema: na experiência brasileira, os recursos públicos são escassos ou tornam-se escassos a partir de uma gestão equivocada? Assim, é razoável a tentativa de buscar uma melhor compreensão do tema para tentar subsidiar uma abordagem jurídica mais abrangente, traduzindo, assim, o porquê deste estudo. Subsiste, então, a questão de como promover essa depuração no debate e, nesse intento, pretende-se confrontar categorias teóricas aparentemente não relacionáveis: i) a lógica econômico-financeira que serve de substrato para a construção do orçamento público, em face da ii) estrutura da fundamentação do discurso judicial que trata dos direitos sociais constitucionais.

As dificuldades são evidentes e consideráveis, já que se tratam de sistemas distintos, com regras próprias, objetivos e métodos distintos. Entretanto, é o percurso necessário. Consoante, o trabalho está dividido em cinco capítulos, iniciando com algumas reflexões acerca do caráter perdulário que marca a definição das prioridades orçamentárias, a partir de exemplos representativos do aspecto voluptuário de alguns gastos públicos, para prosseguir com algumas considerações gerais sobre economia e orçamento, no sentido de evidenciar questões que aparentemente passam despercebidas no debate sobre direito e orçamento. Por fim, pretende-se debater a tese do autoengano e sua importância para compreender a suposta distorção na fundamentação judicial que trata do argumento orçamentário.

\section{A parábola do BMW}

Conforme explicado, a hipótese deste trabalho é que o Estado brasileiro é um administrador financeiro inábil, o que decorreria, principalmente, de uma dificuldade na correta percepção de prioridades no gasto público. É necessário, então, melhor contextualizar a questão. Em 26/01/2016, foi publicada notícia informando a aquisição, pelo Detran-DF, de 14 motos da marca BMW ${ }^{1}$. No dia seguinte foi noticiado que o

O custo individual de aquisição era de $\mathrm{R} \$ 46.324,00$, totalizando mais de seiscentos mil reais. Disponível em: http://www. correiobraziliense.com.br/app/noticia/cidades/2016/01/27/i, 515461/rollemberg-pede-cancelamento-da-compra-de-motos-de- 
Governador do Distrito Federal requereu a suspensão da compra, e, logo após, foi noticiado que o Corpo de Bombeiros do DF já havia comprado motos importadas daquela marca².

Sendo notória a relação entre a referida marca e o mercado de alto luxo, obviamente as notícias causaram espanto, tanto que foram amplamente veiculadas na imprensa. Diversas análises poderiam ser construídas apenas em face do exemplo da compra de motos BMW ${ }^{3}$. Por exemplo, o fato de um Governador de Estado, responsável por um orçamento superior a 34 bilhões de reais ${ }^{4}$ ser obrigado a pessoalmente intervir numa compra de seiscentos mil reais, pela obviedade do absurdo representado pela aquisição, especialmente em razão do momento de estrangulamento financeiro do Governo Distrital, inclusive com atraso de salários ${ }^{5}$.

De toda forma, supõe-se que a aquisição de motos de luxo para patrulhar avenidas da capital federal é um evidente despropósito e caracteriza o que pode ser compreendido como uma alegoria do luxo. Basta considerar que dois aventureiros, em viagem posteriormente documentada em livro, escolheram motocicletas BMW para um trajeto que, iniciando no norte da Escócia, passou pela Tunísia, Líbia, Egito, Sudão, Etiópia, Quênia, Uganda, Ruanda, Tanzânia, Malaui, Zâmbia, Botswana e Namíbia, tinha como destino final a África do Sul ${ }^{6}$.

Aparentemente, as necessidades de transporte para atravessar os continentes europeu e africano são semelhantes às necessidades de transporte de servidores públicos do Distrito Federal. Mais grave, entretanto, é considerar a possibilidade de que a citada alegoria do luxo possa ser uma realidade generalizável na experiência brasileira. Por exemplo, a partir do relatório Prestação de Contas do Detran/DF de 2016 é possível constatar outro exemplo representativo: as receitas (R \$ 410,2 milhões) estavam compostas por receitas diretamente arrecadadas ( $\mathrm{R} \$ 299,8$ milhões) e receitas multa de trânsito ( $\mathrm{R}$ \$110,3 milhões).

No que interessa a este artigo, as despesas: $\mathrm{R} \$ 299,7$ milhões a título de despesas de administração geral e despesas de pessoal. Ou seja, tudo aquilo que é diretamente arrecadado ( $\mathrm{R} \$ 299,8$ milhões) custeia, apenas, a própria estrutura do Detran/DF (R \$299,7 milhões). Todas as outras despesas (engenharia, educação de trânsito, atendimento ao usuário etc.) são custeadas por recursos oriundos das multas de trânsito. Assim, é correto afirmar que o Detran/DF precisa que a lei seja descumprida para que haja recursos que possam ser aplicados na fiscalização e aplicação da lei.

Inobstante, o objetivo desse trabalho não é consolidar um apanhado de notícias sobre abusos nos gastos públicos, mas denunciar que o estado brasileiro é pródigo na realização de despesas desnecessárias e/ou equivocadas. Ao que parece, o Estado brasileiro encerra-se em si, buscando garantir o máximo dos recursos disponíveis para sua própria estrutura. Na literatura sociológica, tal situação envolve um traço cultural que seria perceptível na sociedade brasileira: a dificuldade de formalizar "acordos coletivos duráveis em terra onde todos são barões"».

\footnotetext{
luxo-para-o-detran.shtml. Acesso em: 27 jan. 2016.

$2 \mathrm{Na}$ aquisição realizada pelo Corpo de Bombeiro, foi noticiado que o custo individual das motocicletas foi de $\mathrm{R} \$ 38.000,00$. Disponível em: http://www.correiobraziliense.com.br/app/noticia/cidades/2016/01/28/i,515604/corpo-de-bombeiros-do-dfcomprou-motos-importadas-da-marca-bmw.shtml. Acesso em: 28 jan. 2016.

3 Seria relevante indagar, por exemplo, por que o Corpo de Bombeiros (também do Distrito Federal) considerou adequada a compra de um modelo cujo custo unitário era $18 \%$ mais barato.

4 DISTRITO FEDERAL. Lei ñ 5.601, de 30 de dezembro de 2015. DODF nº 250 (supl.), de 31 dez. 2015.

5 Disponível em: http://g1.globo.com/distrito-federal/noticia/2015/09/gdf-atrasa-beneficios-de-servidores-pelo-segundo-messeguido.html. Acesso em: 11 fev. 2016.

6 MCGREGOOR, Evan; BOORMAN, Charles. Long way down. London: Hachette Digital, 2007.

7 Disponível em: http://www.detran.df.gov.br/prestacao-de-contas-anual.html. Acesso em: 04 jun. 2018.

8 HOLANDA, Sérgio Buarque de. Raǐres do Brasil. 26. ed. São Paulo: Companhia das Letras, 1995. p. 32.
} 


\section{Judicialização da política pública e o custo dos direitos}

É necessário firmar um conceito adequado à expressão judicialização da política, sendo razoável compreendê-la, ao menos neste trabalho, como a lógica jurídico-instrumental que possibilita ao Poder Judiciário adentrar no mérito da política pública para sobrepujar as opções do legislador/administrador e impor as escolhas do Juízo. Obviamente, há defensores e detratores desse tipo de intervenção. Para os primeiros, a judicialização da política é apenas o consequente lógico de um sistema hierárquico-decisório constitucionalmente determinado, ou seja, um subproduto necessário e inevitável da Jurisdição Constitucional.

Não se argumenta que a relação constitucionalismo/judicialização excessiva seja universal, mas apenas que é perceptível no exemplo brasileiro. Afinal, "Se tudo é matéria constitucional haverá uma profusão de incidentes de constitucionalidade que deságuam no Supremo." ${ }^{\prime \prime}$ Em outra via, conforme a doutrina ${ }^{10}$, as críticas à judicialização da política pública envolvem argumentos de duas ordens: i) argumentos de ordem político-institucional, que tratam das questões de legitimidade política do Poder Judiciário (fundamentalmente o problema da separação dos poderes); e ii) argumentos de ordem econômico-financeira, que são debatidos sob o prisma do gasto público ${ }^{11}$.

Nesse contexto, é necessário enfrentar essas questões com a respectiva importância democrática: dada a vedação ao non liquet, o Judiciário deve decidir questões de cunho politico-econômico-orçamentário. Ao fazê-lo, pode sobrepujar as escolhas e/ou omissões do legislador/administrador, superando judicialmente o debate político institucionalizado também porforça da Constituição. Por consequência, o Judiciário deve considerar toda a complexidade do sistema orçamentário-constitucional, que envolve, simultaneamente, elementos espaciais, temporais e funcionais ${ }^{12}$, questões envolvidas num multiverso de contingências e complexidades que não podem ser negligenciadas.

Em suma, e considerando que o Poder Judiciário é convocado rotineiramente a enfrentar questões capitais que envolvem direitos fundamentais e orçamento ${ }^{13}$, é necessário enfrentar o problema do custo dos direitos: enquanto o orçamento é construído com base em uma lógica econômica que envolve a mais adequada alocação dos recursos ${ }^{14}$, a lógica jurídica volta-se a desnaturalizar ${ }^{15}$ a expressão melhor alocação e abordar o tema sob um ideal de justiça. Tal situação permite afirmar que a judicialização das políticas públicas induz a um tipo de transtorno dissociativo de identidade na relação direito/economia-orçamento, já que o Direito se apresenta, concomitantemente, como instrumento de viabilidade e como instrumento de limitação das relações econômicas ${ }^{16}$.

\footnotetext{
VIEIRA, Oscar Vilhena. Supremocracia. Revista Direito GV, n. 8, 2008. p. 446.

10 BUCCI, Maria Paula Dallari. Controle judicial de políticas públicas: possibilidades e limites. Fórum Administrativo - Dir. Público FA, Belo Horizonte, ano 9, n. 103, 2009. p. 9.

11 É razoável supor que o debate sobre o gasto público é ponto central no debate sobre a exigibilidade judicial dos direitos sociais. WANG, Daniel Wei Liang. Escassez de recursos, custos dos direitos e reserva do possível na jurisprudência do STF. Revista Direito GV, São Paulo, jul./dez. 2008. p. 540.

12 Na Constituição Federal, os artigos 165 e seguintes tratam de diversos temas, por exemplo: i) o planejamento regionalizado e federal; ii) orçamentos anuais, diretrizes orçamentárias e plano plurianual (ou seja, questões de curto, médio e longo prazos); iii) o objetivo de reduzir desigualdades inter-regionais (dentre outras funções).

13 Um debate recente envolve ações judiciais para obrigar a distribuição, à custa do Erário, das denominadas "cápsulas contra o câncer" - a fosfoetanolamina. A particularidade mais interessante é que tal farmacológico sequer cumpriu exigências científicas mínimas para receber a denominação de medicamento: "Segundo a decisão do ministro, proferida na Ação Cautelar (AC) 4081, as informações serão necessárias à análise do pedido, uma vez que faltam dados sobre a segurança da substância para a saúde dos pacientes.” Disponível em: http://www.stf.jus.br/portal/cms/verNoticiaDetalhe.asp?idConteudo=307455\&caixaBusca=N. Acesso em: 15 fev. 2016.

14 Essa lógica da melhor alocação dos recursos envolve, então, a relação custo-benefício, “[...] que demanda conhecer e mensurar as vantagens e desvantagens que envolvem a tomada de uma decisão política, como no caso de decidir entre a construção de usina termoelétrica, hidroelétrica ou atômica.”. SILVA, Lino Martins. Contabilidade governamental: um enfoque administrativo da nova contabilidade pública. 8. ed. São Paulo: Atlas, 2009. p. 348.

15 Conforme a doutrina, naturalizar um conceito é selecionar de forma arbitrária e autoritária um dos possíveis modos de pensar a questão, ignorando outras dimensões e significados que poderiam ser considerados e/ou aplicados ao problema em questão. RODRIGUEZ, José Rodrigo. Como decidem as cortes? Para uma crítica do Direito (Brasileiro). Rio de Janeiro: FVG, 2013.

16 GRAU, Eros. Por que tenho medo dos juíres. 6. ed. São Paulo: Malheiros, 2014. p. 15.
} 


\subsection{O paradigma da "suprafundamentalidade"}

No tema das políticas públicas, o Supremo Tribunal consigna que o postulado da dignidade da pessoa humana antecede todo e qualquer rol de direitos constitucionais. A dignidade, assim, seria uma espécie de direito suprafundamental, cuja íntima relação com a intangível ideia de minimo existencial deve guardar as condições de uma existência digna — que ocorreria com a plena fruição de direitos sociais básicos ${ }^{17}$. O referido acórdão ${ }^{18}$ perfaz um exemplo paradigmático nessa discussão, pois, ao mesmo tempo em que declara a escassez de recursos, afirma a impossibilidade de que tal escassez possa inviabilizar quaisquer políticas públicas definidas na Constituição.

Nessa ordem, parece haver contradição performática no raciocínio: se, realmente, há escassez (falta água), é impossível ordenar o atendimento integral da pretensão (matar a sede). Nesse sentido, poder-se-ia no máximo analisar o quanto dos recursos (de água) cada um poderá titularizar individualmente com base nas reais necessidades e disponibilidades. Ademais, em nada ajuda a menção jurisprudencial ao postulado da essencial dignidade da pessoa humana, já que tal postulado não tem o condão de produzir recursos. O debate, então, parece equivocado: ou há escassez de recursos e as pretensões constitucionais não serão integralmente atendidas, ou não há escassez propriamente dita, mas sim um desvio da ordenação de prioridades.

Nesse contexto, o uso dos vocábulos mínimo existencial, reserva do possivel, ou dignidade da pessoa humana são interessantes apenas no que se refere à significação poética, pois são usados para evitar o necessário debate concreto sobre as reais disponibilidades que devem suprir as reais necessidades (e em qual medida). É importante perceber a complexidade que permeia o aspecto funcional das palavras: por exemplo, algo só pode ser considerado excessivamente oneroso em face de um ponto ótimo previamente estipulado, um equilíbrio desejado. Tal equilíbrio, entretanto, vai depender da natureza e tipo específico da relação controversa: “[...] em um contrato de compra e venda de um medicamento de uso contínuo será avaliado segundo certos critérios, enquanto em um contrato de leasing de veículo, a mesma questão será avaliada segundo outros critérios." ${ }^{\text {"9 }}$

Assim, os termos acima, classificados como poéticos, apresentam função avaliatória e, nessa condição distinguem-se daqueles que apresentam função descritiva, sendo especialmente necessário distinguir esse aspecto funcional da linguagem quando se trata do discurso jurídico. O ponto fundamental é compreender que as palavras são utilizadas com base em critérios previamente determinados por aquele que emite a mensagem, e que o uso de termos avaliatórios, sem a necessária explicitação de sentido que demonstre quais critérios foram utilizados por quem discursa, representará um déficit de fundamentação da decisão judicial ${ }^{20}$.

Nesse contexto, o uso da expressão dignidade da pessoa humana, sem a necessária ampliação de sentido, representa, apenas, um conceito naturalizado e formaliza aquilo denominado zona de autarquia, uma falsa justificação das decisões judiciais ${ }^{21}$. $\mathrm{Na}$ essência, a expressão dignidade da pessoa bumana não apresenta um real

\footnotetext{
17 Trecho do julgado: "A cláusula da reserva do possível — que não pode ser invocada, pelo Poder Público, com o propósito de fraudar, de frustrar e de inviabilizar a implementação de políticas públicas definidas na própria Constituição — encontra insuperável limitação na garantia constitucional do mínimo existencial, que representa, no contexto de nosso ordenamento positivo, emanação direta do postulado da essencial dignidade da pessoa humana. Doutrina. Precedentes.” BRASIL. Supremo Tribunal Federal. $A G$. REG. NO RECURSO EXTRAORDINÁRIO COM AGRAVO 639.337/SP, Rel. Min. Celso de Mello. DJe nº 177, publicado em: 15 set. 2011.

18 Sobre o acórdão identificado na nota anterior, é datado de 2011, e posterior ao julgamento da STA 91 (que enfrentou problema do limite material dos recursos como excludente para a obrigatoriedade do Estado em fornecer medicamentos). Daí se permite concluir que a jurisprudência do STF ainda oscila no debate sobre necessidades versus possibilidades, sendo perceptível um padrão argumentativo "[...] que não considera o orçamento público como um meio para se realizar políticas públicas, mas como um obstáculo a elas.” WANG, Daniel Wei Liang. Escassez de recursos, custos dos direitos e reserva do possível na jurisprudência do STF. Revista Direito GV, São Paulo, jul./dez. 2008. p. 547.

19 FREITAS FILHO, Roberto. Intervenção judicial nos contratos e aplicação dos princípios e das cláusulas gerais: o caso do leasing. Porto Alegre: Sergio Antônio Fabris Editor, 2009. p. 153.

20 FREITAS FILHO, Roberto. Intervenção judicial nos contratos e aplicação dos princípios e das cláusulas gerais: o caso do leasing. Porto Alegre: Sergio Antônio Fabris Editor, 2009. p. 153.

21 RODRIGUEZ, José Rodrigo. Como decidem as cortes? Para uma crítica do Direito (Brasileiro). Rio de Janeiro: FVG, 2013.
} 
conteúdo argumentativo que sirva de fundamento para uma decisão judicial no tema "finanças públicas e orçamento". Para confirmar tal afirmação, basta imaginar um cenário hipotético em que há ordem judicial para determinar a internação de pessoa em estágio terminal de câncer na única vaga disponível de Unidade de Terapia Intensiva - UTI ao mesmo tempo em que chega àquela UTI um cidadão acidentado. Nessa hipótese, faz sentido afirmar que a vida (protegida por sentença judicial) é mais digna do que a vida do cidadão acidentado 22 ?

E há inúmeras implicações, como, e.g., a tese da derrotabilidade da norma, essencialmente baseada na premissa de que a norma jurídica pode ser desconsiderada a partir de um contexto factual23. Ora, se a dignidade da pessoa humana justifica a concessão da fosfoetanolamina ${ }^{24}$ para atender um pleito judicial específico, por que restringir os efeitos da decisão apenas para aquela hipotética ação individual? Afinal, se o argumento da dignidade da pessoa humana se presta a superar questões científicas sobre a viabilidade medicamentosa da substância, por que também não derrotar as questões processuais relativas aos efeitos inter partes das decisões judiciais ${ }^{25}$ ?

Portanto, a questão afeita aos custos dos direitos constitucionais deve ser enfrentada com base em um alerta: ainda que exista razão na crítica ao conforto do pragmático, que desconsidera questões teóricas importantes no afã de resolver problemas concretos, também é válida a reprimenda àquilo que agora se denomina de conforto do crítico que, orientado a corrigir "injustiças sociais", faz uso de expressões avaliatórias para dar relevo a proclamações abstratas, desprovidas de real conteúdo normativo ${ }^{26}$ e irresponsáveis em relação às consequências e efeitos derivados ${ }^{27}$.

De qualquer forma, ainda que não devamos confundir as noções de preço e valor ${ }^{28}$, é necessário perceber que a dignidade impõe reflexos no preço, e tal reflexo importa na reflexão sobre a dimensão econômica — o custo-benefício - da política pública judicializada. Assim, ainda que seja evidente o equívoco de tentar reduzir a Teoria do Direito ao utilitarismo, também não se pode olvidar que o Direito é ciência social aplicada e exige um diálogo com outras ciências, inclusive a Economia e seu primado de padrões normativos de avaliaçãa ${ }^{29}$.

Por óbvio, não se pretende defender a ciência racionalista como um tipo de bastião-redentor dos problemas sociais. Sabe-se, nessa quadra histórica, que o conhecimento científico é hipotético e conjectural ${ }^{30}$ dado que

22 É evidente a necessidade de critérios de prioridade a serem observados pelos profissionais competentes, considerando que a limitação de vagas (ou de qualquer outro serviço ou produto médico) é um imperativo de racionalidade, não sendo razoável supor que o Estado deva criar e manter vagas em número suficiente para suprir todas as eventualidades imagináveis.

23 A tese da derrotabilidade supõe que a riqueza da realidade não pode ser predeterminada pelo legislador, e, nessa lógica, seria possível pensar que determinados contextos fáticos teriam o condão de sustar a aplicação da lei. SGARBOSSA, Luís Fernando. Teoria da derrotabilidade: pressupostos teóricos e aplicações. Curitiba: Juruá, 2012. p. 61.

24 Vide nota de rodapé no 14 .

25 Tal situação permitiria que a sentença individual concedesse a substância para todos os elegíveis -aqueles que detivessem uma prescrição médica para o uso da substância. E, além de debater sobre a seletividade daquilo derrotável, quais os outros critérios hermenêuticos necessários para a derrotabilidade da norma? É evidente que a mera ideia de contexto factual é insuficiente — basta lembrar, no exemplo da internação em UTI - que a existência simultânea de dois elegíveis à única vaga para internação também representa contexto factual.

26 É justamente em face de uma jurisprudência estruturada em proclamações abstratas que as críticas ao ativismo judicial soam tão retumbantes: a abstração permite, ao juiz, um maior espaço para faz̧er o que quer, sem controle nem responsabilização. É pertinente o alerta de que "Se o texto não é um pleno de sentido, tampouco a decisão é criadora de um sentido que nunca existira.” FREITAS FILHO, Roberto. Intervenção judicial nos contratos e aplicação dos princípios e das cláusulas gerais: o caso do leasing. Porto Alegre: Sergio Antônio Fabris Editor, 2009. p. 317.

27 Afinal, cabe lembrar, não existe tratamento que não apresente algum tipo de efeito colateral.

28 Aqui, toma-se emprestado o termo valor como sinônimo de dignidade para citar José Reinaldo de Lima Lopes: “O preço é o valor das coisas que se trocam, a dignidade é o valor das coisas que não se trocam.” LOPES, José Reinaldo de Lima. Decidindo sobre recursos escassos: raciocínio jurídico e economia. In: Direitos sociais: teoria e prática. São Paulo: Método, 2006. p. 272.

29 "Além de uma teoria científica do comportamento, a economia fornece um padrão normativo útil para avaliar o direito e as políticas públicas. As leis não são apenas argumentos arcanos, técnicos; elas são instrumentos para atingir objetivos sociais importantes. Para conhecer os efeitos das leis sobre esses objetivos, os juízes e outros legisladores precisam ter um método para avaliar os efeitos das leis sobre valores sociais importantes. A eficiência sempre é relevante para a definição de políticas já que é melhor atingir qualquer política dada a um custo menor do que a um custo mais alto." COOTER, Robert; ULEN, Thomas. Direito e economia. 5. ed. Porto Alegre: Bookman, 2010. p. 26.

30 POPPER, Karl. O mito do contexto: em defesa da ciência e da racionalidade. Lisboa: Edições 70, 1996. p. 158. 
a verdade científica nada mais é do que o momento atual de um paradigma obrigatoriamente precário. Aliás, a denominação hipótese científica decorre justamente da precariedade do paradigma científico — cuja aplicação decorre tão somente de uma falseabilidade ainda não demonstrada: "Por um lado, a teoria de Einstein destruiu não apenas a autoridade de Newton, mas também o autoritarismo da ciência" 31. Não se trata, então, de estabelecer "certezas científicas" no âmbito do Direito, mas de compreender e aceitar o primado da razão enquanto critério de avaliação do discurso jurídico, o que não é possível com o uso de expressões vazias tais como suprafundamentalidades, dignidades ou mínimos existenciais, quando utilizadas sem nenhum tipo de controle linguístico. ${ }^{32}$

\section{0 orçamento como carta de intenções}

É adequado esclarecer que apenas é possível discorrer razoavelmente sobre o critério da reserva do possivel enfrentando argumentos que, a princípio, soam estranhos ao debate jurídico. Talvez essa estranheza seja justamente o cerne do problema, porque parece haver, no âmbito do direito, certa dificuldade em entender as dimensões ontológicas e deontológicas do orçamento, que compreende diversos aspectos (jurídico, político, econômico e técnico-contábil ${ }^{33}$. Há uma pertinente crítica sobre uma denominada visão formalista-tradicional sobre orçamento, descreve que a lei orçamentária estaria fechada a influências externas, "[...] isolada dos contextos histórico, econômico, político e social [...]". ${ }^{34}$

O problema, no particular, é o equívoco de perceber o orçamento como mera formalidade administrativa, em detrimento de entendê-lo como efetivo instrumento de gestão, especialmente pelo fato de que a dimensão gerencial do processo orçamentário - ferramenta de planejamento governamental - está definida no próprio texto constitucional ${ }^{35}$. Ademais, apesar da aparente tautologia, é necessário uma certa maturidade gerencial para compreender a complexidade orçamentária que envolve a importância da receita pública na formatação do princípio do equilíbrio orçamentári ${ }^{36}$. Ora, o debate sobre o argumento orçamentário não perpassa apenas o âmbito das despesas assumidas pelo ente público, mas pela lógica de equilíbrio orçamentário e fiscal que deve ser considerada pelo administrador público.

Lembrando o texto-padrão da ementa de qualquer lei anual de orçamento (o trecho "Estima a receita e fixa a despesa [...]"), cabe compreender que a receita pública é uma estimativa, uma grandeza conceitualmente dinâmica que varia conforme a assertividade dos critérios utilizados na estimativa, numa ordem diretamente proporcional $^{37}$. Por exemplo, se o administrador subavaliar o impacto da sonegação fiscal — critério estatisticamente aferível — a receita efetiva será inferior àquela prevista. Por conseguinte, a receita efetiva não atenderá à integralidade das despesas previstas inicialmente e exigirá algum tipo de realocação dos recursos.

\footnotetext{
31 POPPER, Karl. O mito do contexto: em defesa da ciência e da racionalidade. Lisboa: Edições 70, 1996. p. 155.

32 Cabe lembrar que os críticos de Copérnico não estavam exatamente certos, nem errados: "Parte do que entendiam pela expressão "Terra" referia-se a uma posição fixa. Tal Terra, pelo menos, não podia mover-se. Do mesmo modo, a inovação de Copérnico não consistiu simplesmente em movimentar a Terra. Era antes uma maneira completamente nova de encarar os problemas da física e da astronomia, que necessariamente modificava o sentido das expressões "Terra" e "movimento". KUHN, Thomas $\mathrm{S}$. $A$ estrutura das revoluções científicas. 12. ed. São Paulo: Perspectiva, 2013. p. 248.

33 AGUIAR, Afonso Gomes. Direito financeiro: a lei 4.320 - comentada ao alcance de todos. 3. ed. Belo Horizonte: Fórum, 2008. p. 33.

34 CONTI, José Maurício; SCAFF, Fernando Facury (coord.). Orçamentos públicos e direito financeiro. São Paulo: Revista dos Tribunais, 2011. p. 977.

35 SILVA, Lino Martins. Contabilidade governamental: um enfoque administrativo da nova contabilidade pública. 8. ed. São Paulo: Atlas, 2009. p. 171.

36 "No momento da elaboração do orçamento, o montante fixado para as despesas seja, igualmente, o mesmo valor previsto para as receitas." AGUIAR, Afonso Gomes. Direito financeiro: a lei 4.320 - comentada ao alcance de todos. 3. ed. Belo Horizonte: Fórum, 2008. p. 43.

37 Quanto maior a assertividade dos critérios maior será o resultado apurado a título de receita.
} 
Consoante, debater o critério da reserva do possível apenas em face da despesa é uma forma equivocada de análise, pois olvida a importância da estimativa das receitas em relação ao equilíbrio orçamentário e em relação às reais expectativas e possibilidades orçamentárias. Tal questão é especialmente sensível quando se constata a possibilidade de existência de uma ilegítima manipulação na estimativa das receitas, no sentido de distorcê-la até que os valores estimados satisfaçam formalmente as previsões legais que tratam do equilíbrio e responsabilidade fiscal.

Nessa lógica, as receitas não seriam tecnicamente mensuradas, mas politicamente fixadas no sentido de alcançar um equilíbrio orçamentário meramente formal, descaracterizando qualquer pretensão de tecnicidade orçamentária. Lembrando da importância dos efeitos da atividade econômica (produção de riqueza) sobre a receita pública (apropriação de parcela da riqueza pelo Estado), a variabilidade daquela atividade econômica formata o argumento da imprevisibilidade da economia. Por sua vez, essa imprevisibilidade parece ser o pilar da hipótese de manipulação na estimativa das receitas ${ }^{38}$.

Esse ponto é fundamental, pois representa com assertividade aquilo que se percebe na práxis, em que há dados que sugerem que a estimativa da receita se dá com base em critérios profundamente questionáveis e permite afirmar que o orçamento público brasileiro é tratado como mera carta de intenções. De fato, há desafios na formulação de expectativas econômicas assertivas, e tal situação é parodiada até pelos especialistas: "É verdade que os mercados de ações podem prever os ciclos econômicos. O mercado de ações previu nove das últimas cinco recessões" 39 . Entretanto, ainda que se reconheçam as dificuldades, o administrador não fica autorizado a ignorar o conteúdo técnico do orçamento, e muito menos a necessidade de considerar o orçamento a partir de sua dimensão gerencial.

\subsection{A dimensão gerencial da política pública: uma notável desconhecida}

Um alerta inicial: gerenciar não é, per se, cortar luxos (o que poderia ser equivocadamente deduzido da parábola do $B M W)$, mas é medir, parametrizar, planejar, implementar, controlar, revisar e auditar. Assim, uma politica gerencial deve considerar premissas e condições, determinar metas e estabelecer as ações necessárias para a concretização do resultado, considerando ainda os custos envolvidos ${ }^{40}$. Um segundo alerta: o trabalho acadêmico demanda um corte metodológico, que tanto será arbitrário quanto necessário. Assim, é necessário superar algumas questões orbitais (e.g., o enredo histórico da tentativa de modernização da burocracia brasileira na era Vargas, ou o problema sobre a burocracia weberiana como modo de dominação), e iniciar esta análise em meados da década de 1990, quando o Brasil teria adotado o ideário do new public management ${ }^{41}$.

Também cabe ressaltar que não há a intenção de defender o modelo gerencial como a melhor ou única forma de refletir sobre a Administração Pública, mas apenas ressaltar a importância de referências e conceitos fundamentais, aparentemente negligenciados na experiência brasileira ${ }^{42}$. Superados os alertas, veja-se

\footnotetext{
38 Veja-se que a legislação em vigor determina que a variação do Produto Interno Bruto-PIB seja observada nas propostas orçamentárias. BRASIL. Lei Complementar 101, de 04 de maio de 2000. DOU no 86, de 05 maio 2000.

39 Frase proferida por Paul Samuelson, ganhador do prêmio Nobel de economia no ano de 1970. Disponível em: http://www1. folha.uol.com.br/fsp/dinheiro/fi1412200913.htm. Acesso em: 18 fev. 2016.

40 Qualquer exercício mental é capaz de evidenciar que, dadas condições específicas, há um modelo ideal de alocação de recursos. Por exemplo: dadas condições bioquímicas próprias, a quantidade de calorias ingeridas e calorias gastas apresenta um resultado ideal (peso adequado) ou não (desnutrição ou sobrepeso). Por sua vez, a correção do resultado não-ideal envolve custos financeiros (e.g., meios para entrar em contato com o nutricionista) e não financeiros (o esforço pessoal de observar a dieta).

41 É razoável afirmar que os temas da reforma administrativa e da administração pública gerencial apenas voltam à discussão política no Brasil a partir de 1994. MATIAS-PEREIRA, José. Curso de administração pública: foco nas instituições e ações governamentais. 2. ed. São Paulo: Atlas, 2009.

42 Ana Paula Paes de Paula descreve que a ideia de nova administração pública pareceu, naquele momento, o modelo ideal para o gerenciamento do Estado, prescrevendo, entretanto, um outro modelo que considera mais adequado: um tipo de ponderação entre administração pública gerencial e o que ela denomina de administração pública societal. PAULA, Ana Paula Paes de. Por uma nova gestão pública: limites e potencialidades da experiência contemporânea. Rio de Janeiro: Editora FGV, 2005.
} 
que, a partir do quadriênio 2000/2003, a gestão federal foi organizada em ações governamentais (programas), estruturadas sob a forma de ciclo de gestão, entendido como um modelo de atuação segmentado em formulação (planejamento), implementação (execução) e avaliação (controle e auditoria).

Por exemplo, confira-se a Lei 9.989 de 21/07/2000: o Anexo I descreve diretrizes estratégicas e macro-objetivos para (dentre outros objetivos) modernizar a infraestrutura a melhorar serviços de telecomunicaçoes; o Anexo II-A formaliza o programa 0274 (energia elétrica), com o objetivo de assegurar condições para o pleno atendimento aos consumidores, fixando ações/metas/custos (por exemplo, ação cód. 2409, tipo A, Autorização de construção de pequena central hidroelétrica, $R \$ 789.150$ ); por fim, o Anexo III apresenta ainda os valores totais porprograma (por exemplo - Programa 0274 - Valor PPA 2000-2003 - R\$109.809.169,00).

O relato acima apresenta um modelo de gestão que parametriza objetivos, condições, ações e custos, ou seja, uma predeterminação de intenções e uma vinculação orçamentária. Tal situação: i) exige do administrador clareza de propósitos; ii) exige que os objetivos pretendidos sejam organizados em face do orçamento; e iii) torna factível o monitoramento da atuação do administrador em face do planejamento realizado. Esse paradigma evidencia a importância do orçamento enquanto ferramenta de gestão que viabiliza a materialização das escolhas políticas do administrador.

Nesse momento, talvez fosse possível supor uma contradição neste texto: se, na década de 1990, o país adotou a nova gestão pública, e, na década de 2000, adotou a gestão programática, como afirmar aqui que a dimensão gerencial da política pública é desconhecida? De forma mais imediata e simplista, a resposta envolve a distinção entre o plano do discurso e o plano da ação, aquela separação entre discurso e conduta que é absolutamente corriqueira no plano político brasileiro. No ponto, a doutrina sociológica explica que a linguagem pode operar uma divisão na realidade política: um contexto institucional, ou seja, o mundo normativo que é ostensivo e público; e um contexto factual, aquilo que estaria de fato acontecendo, que existe nos bastidores das reuniões fechadas ${ }^{43}$.

Ademais, para explicar a suposta contradição aludida acima, também é possível arriscar uma resposta mais complexa, estruturada em duas razões: uma razão jurídico-cultural (que será explicada em outro tópico) e uma razão técnico-orçamentária. A resposta técnico-orçamentária envolve aquela citada dificuldade na compreensão das diversas dimensões do orçamento e supõe que a inabilidade financeira do Estado decorre de uma inabilidade administrativa, constatável ainda na fase inicial do ciclo de gestão (o planejamento).

Supõe-se que não há clareza sequer na construção teórica do conceito de orçamento, justamente o problema de ser percebido como carta de intenções. Conceitualmente distorcido e funcionalmente ineficaz, o orçamento só pode existir enquanto instrumento meramente formal, desconectado do processo de tomada de decisões.

\subsection{Um exemplo sobre planejamento orçamentário}

Considerando-se a universalidade de fatores que impactam a execução orçamentária, talvez fosse possível concluir pela possibilidade de uma legítima frustração da receita pública ${ }^{44}$. Entretanto, tal hipótese não parece adequada na experiência brasileira, pois há sólidos argumentos que sustentam a ideia de manipulação na estimativa das receitas. Tal situação, se confirmada, representaria a própria essência do desequilíbrio orçamentário, pois o orçamento já nasceria desequilibrado por uma estrutura de despesas financeiramente inviável: as despesas não estariam efetivamente albergadas por estimativas realistas de receitas, mas apenas formalmente albergadas por estimativas ficcionais ${ }^{45}$.

43 ABREU, Luiz Eduardo. A troca das palavras e a troca das coisas: política e linguagem no Congresso Nacional. Revista Mana, Rio de Janeiro, v. 11, n. 2, 2005.

${ }_{44}$ Por exemplo, aumento de impostos (que pode resultar em desvio na curva padrão de sonegação e ter efeito negativo nas receitas), inflação, despesas extraordinárias decorrentes de calamidades etc.

45 É o que se percebe, por exemplo, na análise do planejamento perpetrado pela lei de diretrizes orçamentárias do ano de 2013 e a subsequente lei de orçamento de 2014. Cabe explicar que o exercício de 2014 foi escolhido por um critério de proximidade temporal 
Por exemplo, em janeiro/2014, a Lei de Orçamento fixou a receita pública no valor de 2,3 trilhões de reais $^{46}$. Ao final daquele exercício, a receita efetivamente auferida totalizou 2,2 trilhões de reais ${ }^{47}$, uma diferença aproximada de 6\% que, a princípio, não parece colossal ou absurda. Entretanto, em termos financeiros, tal diferença equivale ao montante de $\mathrm{R} \$ 153$ bilhões, valor relevante em qualquer análise, especialmente em face de um parâmetro comparativo: no mesmo ano de 2014, aquela citada Lei 12.952/2014 fixou o gasto total com o Ministério da Saúde no valor 106 bilhões de reais.

A comparação com o orçamento anual do Ministério da Saúde é deliberada, pois é justamente nas ações judiciais relativas ao direito de saúde que o argumento da reserva do possível se torna tão etéreo: como dizer que faltam verbas para a saúde, quando apenas o erro da estimativa da receita pública foi equivalente a 144\% do valor de todo orçamento para a saúde pública? Ademais, e supondo que a própria existência de demandas judiciais relativas à saúde demonstra, em alguma medida, uma inexatidão do planejamento público ${ }^{48}$, talvez a pergunta mais óbvia: quanto custa o sistema de saúde oferecido e quanto custaria aquele que deveria ser oferecido?

Assim, o problema envolve um grau de perpetuação de carências e corrobora a tese de planejamento inadequado, já que o processo de gestão envolve a atividade de rever (a fase de controle) tanto a execução quanto o planejamento, justamente para corrigir os problemas verificados. E há questão mais delicada, que envolve não apenas o problema burocrático de gestão deficiente, mas o problema político que se constata pela formatação, consciente e irresponsável, de estimativas de receita baseadas naqueles citados critérios poéticos.

Por óbvio, uma estimativa fictícia da receita pública invalida qualquer validade do argumento da reserva do possível: não é possível argumentar sobre escassez de recursos, quando o próprio Estado não estipula suas receitas e despesas dentro de uma racionalidade econômica mínima. Seria como um devedor civil que se negasse a pagar suas dívidas com base no argumento de que a receita da "rubrica loterias e jogos de azar - mega-sena e jogo do bicho", considerada no orçamento pessoal, não houvera se concretizado ${ }^{49}$. Aliás, essa anedota também resume a alegoria do $B M W$ suscitada neste trabalho: o devedor assume despesas obrigatórias, facultativas e voluptuárias para além das receitas factíveis para depois usar o argumento de que não há verbas para cumprir a integralidade das despesas obrigatórias.

A questão, então, passa pela análise da afirmação de que o Estado considera no orçamento receitas não realizáveis, havendo pelo menos um argumento que suporta tal afirmação — justamente a importância da economia para a receita pública ${ }^{50}$. Assim, as prospecções sobre o crescimento do PIB não são tão etéreas quanto parecem em primeira análise, e são explicitamente consideradas nas propostas orçamentárias (conforme dispõe o artigo $4^{\circ}$ da Lei de Responsabilidade Fiscal - LRF ${ }^{51}$ ). Confira-se a Tabela 1 (Parâmetros Macroeconômicos Projetados), no Anexo IV (metas fiscais anuais) da Lei de Diretrizes Orçamentárias de $2013^{52}$ - que registra as expectativas estatais para economia o ano de 2014: o PIB teria um crescimento real de 4,5\% ao ano; a taxa selic efetiva encerraria no percentual de 7,28\% ao ano; o dólar encerraria o ano na cotação de $\mathrm{R} \$ 2,06$.

Comparando aquelas expectativas estatais com aquilo efetivamente verificado em 2014: o crescimento

com a construção deste texto (iniciado em 2016).

46 BRASIL. Lei 12.952 de 21 de janeiro de 2014. DOU no 14 de 21 jan. 2014.

47 Disponível em: http://www8d.senado.gov.br/dwweb/abreDoc.html?docId=92787. Acesso em: 28 fev. 2016.

48 De fato, há situações imprevisíveis que escapam a qualquer planejamento. Entretanto, a excepcionalidade não parece ser o caso das atuais demandas de saúde, como bem exemplifica o trabalho de Daniel Wang. WANG, Daniel Wei Liang. Escassez de recursos, custos dos direitos e reserva do possível na jurisprudência do STF. Revista Direito GV, São Paulo, jul./dez. 2008.

49 Esse argumento de tipo reductio ad absurdum é válido justamente porque se pretende argumentar que a diferença entre receita estimada e receita auferida, na experiência brasileira, está mais relacionada com uma deliberada e intencional distorção na estimativa da receita do que com aquilo que seria razoável em termos de oscilação natural das estimativas.

50 Quanto maior a atividade econômica, maiores serão as receitas públicas: “[...] deve ser realçado que o orçamento público se funda no valor da parcela da renda nacional, ou produto nacional bruto que lhe é destinada para garantir o custeio das ações governamentais [...]". AGUIAR, Afonso Gomes. Direito financeiro: a lei 4.320 - comentada ao alcance de todos. 3. ed. Belo Horizonte: Fórum, 2008. p. 37.

51 BRASIL. Lei Complementar 101, de 04 de maio de 2000. DOU no 86, de 05 maio 2000.

52 BRASIL. Lei 12.919 de 26 de dezembro de 2013. DOU de 26 dez. 2013 - ed. extra. 
real do PIB foi de $0,1 \%{ }^{53}$; a taxa selic (efetiva) fechou no percentual de $11,65 \%$ ao ano ${ }^{54}$, e o câmbio encerrou o ano com US $\$ 1$ cotado a $R \$ 2,65^{55}$. Não apenas as previsões governamentais foram frustradas, mas os percentuais de erro foram substanciais, dando relevo a uma questão fundamental: quais os fundamentos para a previsão de crescimento do PIB realizada pelo administrador para o ano de 2014, da ordem de 4,5\%? Ao que parece, havia apenas fé - e uma excelente campanha publicitária voltada para a eleição daquele ano — especialmente quando se constata a divergência prévia (ainda em janeiro/2014) de informações econômicas havida entre governo e mercado:

São Paulo, 13 de Janeiro de 2014 - Depois de mais um resultado abaixo das expectativas em 2013, o mercado financeiro brasileiro decidiu melhorar um pouco suas projeções para o crescimento da economia até o fim de 2014. De acordo com o Relatório Focus do dia 10 de Janeiro, o Produto Interno Bruto (PIB) brasileiro crescerá 1,99\% nesse ano. No relatório anterior, de 03 de Janeiro, a previsão era de uma alta de apenas $1,95 \%$ até o fim de $2014 .{ }^{56}$

Para aqueles que acompanham rotineiramente o tema, é notória a dissonância entre Estado e mercado em relação às informações econômicas em geral, como exemplifica o ano de 2014: a) o Estado afirma em lei que o PIB vai crescer 4,5\%; b) o mercado projeta que o PIB vai crescer 1,99\%; c) o PIB efetivamente cresceu $0,1 \%$. Alguns podem supor que o mercado atua com projeções autorrealizáveis, numa espécie de política econômica antiestatal; outros podem dizer que, em 2014, tanto o Estado quanto o mercado erraram em suas projeções.

$\mathrm{Na}$ primeira hipótese parece improdutivo discutir teorias econômicas conspiratórias neste trabalho; na segunda, parece inadequado equiparar equívocos de gradação distintos, já que, na dimensão do PIB brasileiro, um erro de 4,4\% é bem diferente do erro de 1,98\%. Assim, com base na ideia da Navalha de Ockham ${ }^{57}$, alude-se à terceira hipótese: o Estado atua com projeções orçamentárias fictícias no sentido de manter um programa de marketing político-eleitoral, legando para dezembro/ano a prova do erro perpetrado em janeiro/ano, em um sistema de equívocos orçamentários que é anualmente renovável e objetiva primariamente manter o status quo político.

\section{$5 \mathrm{Na}$ essência do problema}

Mais importante, ninguém, em nenhum nível, pode confiar em mais ninguém; os "números” são piadas. E, quando a "disciplina dos números" se vai, o mesmo acontece com restante da disciplina. Os marcos não são atingidos. As promessas não são cumpridas. As más notícias são ocultadas ou distorcidas ${ }^{58}$.

Relembrando os citados vetores do argumento orçamentário (a reserva do possível versus a impossibilidade de frustração de direitos constitucionais), parece correto afirmar que o trabalho de Daniel Wang, quando

\footnotetext{
53 Disponível em: http://www1.folha.uol.com.br/mercado/2015/03/1608985-pib-cresce-01-em-2014-aponta-ibge.shtml. Acesso em: 28 jan. 2016.

54 Disponível em: https://www.bcb.gov.br/Pec/Copom/Port/taxaSelic.asp. Acesso em: 28 jan. 2016. Há uma diferença técnica entre a taxa Selic META (fixada pelo Comitê de Política Monetária) e taxa selic efetiva (média das taxas praticadas nas operações), mas tal distinção não é relevante neste trabalho.

55 Disponível em: http://economia.uol.com.br/cotacoes/cambio/dolar-comercial-estados-unidos/?historico. Acesso em: 28 jan. 2016.

56 Disponível em: http://br.advfn.com/jornal/2014/01/boletim-focus-aponta-para-crescimento-do-pib-bem-abaixo-do-estimado-pelo-congresso-nacional. Acesso em: 28 jan. 2016. Apesar de o Boletim Focus ser publicado pelo Banco Central, trata-se de projeções sobre a economia brasileira coletadas junto a alguns dos principais economistas em atuação no país - ou seja, é uma avaliação realizada pelo mercado. Disponível em: https://bradvfn.com/economia/boletim-focus. Acesso em: 05 abr. 2017.

57 Brocardo de senso comum: se em tudo o mais forem idênticas as várias explicações de um fenômeno, a mais simples é a melhor.

58 PETERS, Tom. Prosperando no caos. São Paulo: Harbra, 1989. p. 507. É interessante notar que essa citação foi redigida no longínquo ano de 1989, em contexto absolutamente diverso (mercado corporativo privado) mas ainda assim é pertinente ao aqui e agora das políticas públicas brasileiras e do debate judicial decorrente.
} 
analisou a jurisprudência do Supremo ${ }^{59}$, foi assertivo em argumentar que o Judiciário desconsidera o critério da reserva do possível, por exemplo, em questões relativas ao direito da saúde, mas acolhe-o quando se depara com os argumentos orçamentários em outras áreas, como a questão dos precatórios, onde a Corte teria mais cuidado na análise das finanças do ente público.

Entretanto, o referido trabalho não atentou para a parábola do BMW aqui suscitada, pois analisar as finanças do ente público não é conferir rubricas orçamentárias totalizadas (percentuais globais de gastos), ou proclamar que a hipótese de despesas maiores que receitas importa a legítima impossibilidade do descumprimento de obrigações ${ }^{60}$. Bem verdade, conferir contas totalizadas é método de tergiversação, pois olvida que, na fase de planejamento orçamentário, o ente público assumiu despesas obrigatórias mas também assumiu despesas facultativas e voluptuárias. Afinal, a diferença de valor entre uma moto BMW e o modelo equivalente produzido no Brasil não parece constituir despesa obrigatória.

Torna-se necessário, portanto, apurar o quanto da diferença entre receitas e despesas decorre de uma opşão voluntária do administrador, justamente porque, repete-se, a estimativa de receitas não factíveis se apresenta como o pressuposto metodológico para a construção de um orçamento poético. Portanto, se há uma fictícia estimativa das receitas, é necessário abordar a própria estrutura de gastos fixada no orçamento, justamente para apurar o quanto do gasto é despesa realmente obrigatória. Aliás, conforme a lei de Responsabilidade Fiscal, o gasto com pessoal deve ser limitado a um percentual da receita ${ }^{61}$. Assim, os efeitos de uma abordagem verossímil do orçamento podem ser imediatos e severos, já que a receita pública corretamente estimada poderia importar a imediata adoção das medidas restritivas e punitivas previstas — quando as despesas com pessoal ultrapassam os limites fixados.

Novamente no fio condutor deste trabalho, mas de forma menos alegórica: ao debater o argumento da reserva do possível, é necessário que o Poder Judiciário analise quanto efetivamente é gasto para satisfazer os gostos da burocracia, a exemplo de motos BMW ou outros luxos cotidianamente oferecidos à oligarquia tecnocrata, para usar a expressão de Paulo Bonavides ${ }^{62}$. Ainda que tais despesas possam ser irrelevantes do ponto de vista fiscal, devem ter relevo do ponto de vista jurisdicional, pois, se há uma fila de espera para atendimento básico de saúde, apenas é válido o argumento orçamentário da reserva do possivvel na perspectiva de uma complexidade orçamentária, no sentido de avaliar a ordenação das prioridades na fixação das despesas e o paradigma da melhor alocação de recursos.

Portanto, se o Poder Judiciário pode ou deve debater questões políticas judicializadas, deve considerar também as outras dimensões pertinentes na análise, pois, repete-se, analisar as finanças públicas não é adentrar em contas totalizadas para aferir percentuais globais de gastos, mas debater desde o planejamento fiscal até o orçamento executado, e analisar, com profundidade: a) quanto é gasto; b) em que é gasto; c) por que é gasto. Sem uma exaustiva análise sobre tais pontos, tem-se uma jurisprudência absolutamente superficial, particularmente nociva por não se apresentar como uma efetiva declaração do poder público sobre os valores protegidos pelo Judiciário.

E aqui se retoma um ponto do capítulo 3.1 deste trabalho, para tratar da segunda parte da resposta ao problema do desconhecimento da dimensão gerencial do orçamento. Ao que parece, há uma cultura jurí-

\footnotetext{
59 O autor também explica que, nas ações relativas à intervenção federal para pagamentos de precatórios, há uma preocupação dos ministros para conhecer a situação concreta das finanças públicas. "É uma postura diferente das decisões que envolvem direito à educação e à saúde, em que, geralmente, não há nenhuma preocupação em se analisar os custos daquilo que se pede em juízo nem a possibilidade fática de o Estado cumprir a decisão tento em vista as diversas outras obrigações que possui.". WANG, Daniel Wei Liang. Escassez de recursos, custos dos direitos e reserva do possível na jurisprudência do STF. Revista Direito GV, São Paulo, jul./ dez. 2008. p. 562.

${ }^{60}$ "Na mesma linha, o Ministro Celso de Melo julgou improcedente o pedido de intervenção federal no Estado de São Paulo, uma vez que não houve intenção no descumprimento da lei, e este demonstrou que o não pagamento deu-se por insuficiência de recursos, já que as despesas são maiores que as receitas correntes líquidas [...]”. WANG, Daniel Wei Liang. Escassez de recursos, custos dos direitos e reserva do possível na jurisprudência do STF. Revista Direito GV, São Paulo, jul./dez. 2008. p. 561.

${ }_{61}$ Confira-se, e.g., o art. 19 da LRF. BRASIL. Lei Complementar 101, de 04 de maio de 2000. DOU no 86, de 05 maio 2000.

62 BONAVIDES, Paulo. Reflexões: política e direito. 2. ed. Rio de Janeiro: Forense, 1978. p. 27.
} 
dica refratária ao debate matemático e político-instrumental que envolve o orçamento. Um forte indício desse fato é a própria jurisprudência proclamatória, como se proclamações jurídicas tivessem o condão de gerar recursos. Em suma, parece que o Executivo e o Legislativo fazem uso formal e estratégico do debate orçamentário, e o Judiciário sela os equívocos anteriores ao negar-se a enfrentar o problema de fundo. Ora, é justamente a existência de normas constitucionais e legais sobre a dimensão gerencial do orçamento que exige do Judiciário uma jurisprudência consistente do ponto de vista da complexidade orçamentária ${ }^{63}$.

Por exemplo: uma ordem judicial para a realização de uma despesa extraordinária de saúde (sob o argumento de salvar uma vida - o autor da ação) será simplória e equivocada se não enfrentar os subsequentes efeitos da reorganização do orçamento, bastando lembrar que tal reorganização poderia retirar verbas de ações de fiscalização de trânsito que podem evitar outra(s) morte(s). E não se trata de debater o abstrato (o possível dano no trânsito) em detrimento do concreto (o autor da ação), considerando os dados da Organização Mundial de Saúde (Global Status report on road safety 2015): o trânsito brasileiro é responsável por mais de 42 mil mortes/ano ( 5 óbitos por hora) ${ }^{64}$ - não havendo absolutamente nada de abstrato no debate político, jurídico e orçamentário sobre as demandas de segurança no trânsito.

No mundo empírico das políticas públicas, não parece adequado um tipo de pensamento jurídico que abraça e festeja princípios e valores abstratos ${ }^{65}$ em detrimento de complexidades reais, em que o fornecimento de um fármaco não se dá apenas por força de uma declaração judicial, mas depende um complexo funcional de cadeias produtivas primárias, secundárias, dependentes e complementares ${ }^{66}$. Tal abstração principiológica não apenas é estéril, mas é perigosa na medida em que se arvora de um certo tipo de moral bumanista abstrata para realizar intervenções parciais e circunstanciais em sistemas complexos, sem atentar para os efeitos sistêmicos daquelas intervenções.

Ou seja, simplesmente escrever dignidade da pessoa humana e cumpra-se não pode resumir a responsabilidade do Poder Judiciário ${ }^{67}$, até mesmo por que não parece razoável supor que caiba ao Judiciário atuar como varejista/ intermediário de medicamentos ou serviços em caráter rotineiro, em face de uma permanente omissão no cumprimento de deveres sociais por parte das autoridades competentes. Ainda que tal atuação varejista tenha importância, pois efetivamente atende o indivíduo que deveria ser protegido pelo Estado, está equivocada enquanto dissociada da complexidade e da universalidade que envolvem a questão das políticas públicas.

\section{0 autoengano}

Todo o exposto permite concluir que o debate orçamentário está consideravelmente equivocado: pior que o simples desconhecimento é a ignorância potenciada de uma falsa certeza $a^{68}$. Um hipotético caso sobre a fosfoetanola-

\footnotetext{
63 Nesse sentido, a questão de fundo é a percepção reduzida da real importância da jurisprudência enquanto instrumento de orientação social, pois o direito é um sistema social de estabilização de expectativas. LUHMANN, Niklas. Sociologia do direito I. Rio de Janeiro: Edições Tempo Brasileiro, 1983. p. 121.

64 Disponível em: https://www.who.int/violence_injury_prevention/road_safety_status/2015/en/. Acesso em: 04 jun. 2018.

65 Ao tratar da efetividade das normas constitucionais, que alude como um dos marcos do neoconstitucionalismo, Luiz Roberto Barroso explica: "No plano jurídico, atribuiu normatividade plena à Constituição, que se tornou fonte de direitos e de obrigações, independentemente da intermediação do legislador." BARROSO, Luís Roberto. Curso de direito constitucional contemporâneo: os conceitos fundamentais e a construção do novo modelo. 5. ed. São Paulo: Saraiva, 2015. p. 518.

66 Por exemplo: recursos humanos, pesquisa, insumos, produção, logística, transporte, estoque, armazenamento, controle de efeitos colaterais etc.

${ }^{67}$ Especificamente sobre a jurisprudência do STF, é razoável supor que: i) não produz reflexões suficientemente densas sobre os temas justiça e distribuição; ii) não adentra nas particularidades necessárias de uma hermenêutica voltada à concretização de direitos dependentes de políticas públicas; iii) não trata de forma razoavelmente unívoca os conceitos de "políticas públicas", "direito à saúde", "direito à educação" e "direito à segurança", sequer reconhecendo as diferenças e convergências. LIRA, Daiane Nogueira et al. Políticas públicas e protagonismo judicial no STF: relatório de pesquisa do grupo de estudo e pesquisa em políticas públicas e hermenêutica. Revista Universitas JUS, Brasília, v. 22, n. 2, p. 105-196, jul./dez. 2011. p. 106.

68 GIANETTI, Eduardo. Auto-engano. São Paulo: Companhia das Letras, 2005. p. 11.
} 
mina ${ }^{69}$ bem caracterizaria a cadeia de autoenganos em que se encontra o debate atual: a) o autor pediria um direito à saúde em caráter absoluto sem enfrentar a problemática de que a pretensão pode, na verdade, importar em dano à saúde ${ }^{70}$; b) o sistema público de saúde negaria o atendimento sob o argumento da reserva do possível, sem adentrar o mérito do planejamento fiscal e sem discorrer sobre as escolhas administrativas realizadas; c) o Judiciário enfrentaria as questões emitindo proclamações superficiais sobre dignidade, com base na análise de despesas totalizadas. Todos os atores da cena enganando-se a si mesmos e mutuamente, com base em mal-entendidos espontâneos:

Conclui-se, então, que Deus mentiu? Que tentou abafar a aspiração humana de conhecimento e transcendência com uma falsa ameaça? Não necessariamente. No sentido literal da verdade, por estranho que pareça, a serpente foi mais honesta que Deus. O que transparece, contudo, é que a morte a que Deus se referia em sua ameaça não era a morte súbita e literal do organismo, mas a consciência antecipada da morte - a experiência aguda da amarga condição de finitude que nos junta e separa, liga e arranca da união com tudo o que vive. $\mathrm{O}$ engano original da queda, portanto, teria partido de um engano de entendimento acerca da palavra divina. A serpente não mentiu. O que ela fez foi explorar a porta aberta por um mal-entendido espontâneo, ou seja, pela atribuição ingênua e indevida de literalidade a uma ameaça igualmente real ${ }^{71}$.

Considerando que a sociedade brasileira atualmente compreende o Judiciário como um ator politicamente apto para adentrar no mérito das políticas públicas, deve também exigir que assuma as respectivas responsabilidades e explique, no contexto das políticas públicas, se Deus mentiu. Não basta formular proclamações abstratas, sendo necessário revisar as premissas sobre teorias jurídicas e realidade brasileira para compreender que, ainda que seja prudente e necessário pensar com base em categorias teóricas mais abstratas, há um aqui e agora mais simplório, e.g., hierarquizar aquilo que configura uma despesa obrigatória.

Reconhecendo que a "familiaridade representa um desvalor enquanto critério de conhecimento, pois mitiga o esforço de conhecer", é necessário que "por mais que se conheça, sempre é possível conhecer mais"72, o que exige um trabalho jurisdicional de efetivamente atestar se há (ou não) recursos disponíveis, e que esteja organizado sob a forma de uma fundamentação universalizável e apta a explicitar qual a conduta conforme a regra que deve ser observada pela sociedade, inclusive sob a perspectiva de uma legitimidade democrática, no sentido de formalizar um tipo de controle da autoridade jurisdicional ${ }^{73}$.

É necessário, e.g., enfrentar o autoengano para reconhecer que não há planejamento estatal adequado, e basta conferir o problema da judicialização da saúde para atestar tal fato: no mínimo, o planejamento deveria observar alguma mensuração estatística das demandas ajuizadas e ajuizáveis, no sentido de integrar o custo judicial projetado no próprio orçamento da saúde. Nessa hipótese, é razoável supor que parcela das demandas judiciais fundadas no argumento da reserva do possível restaria eliminada, já que a verba judicial para saúde já estaria contemplada no orçamento, ao menos enquanto despesa projetada. E sequer caberia o argumento de que a despesa com a intervenção judicial cresce anualmente, sendo impossível sua mensuração: a variação anual da rubrica, per se, já representa um dos critérios para a fixação de um custo judicial projetado.

De fato, é absolutamente curioso constatar que o mercado de bairro consegue manter um estoque razoavelmente adequado de alface e outros perecíveis, enquanto a gestão pública de saúde apresenta dificuldades

\footnotetext{
69 $\quad$ Vide nota de rodapé $\mathrm{n}^{\circ} 14$.

70 A incapacidade reprodutiva é um dos efeitos esperados da farmacologia quimioterápica. Poder-se-ia afirmar que aquele acometido pelo câncer prefere sobreviver a reproduzir (e tal efeito colateral não importaria na efetividade da fosfoetanolamina). Entretanto, uma falência renal decorrente do uso de medicamento leva a óbito tal qual uma falência pulmonar decorrente de uma metástase do câncer de pulmão — ou seja, qualquer medicamento pode apresentar efeitos colaterais tão severos quanto a patologia que pretende curar. Assim, é relevante a diferença entre os efeitos de farmacologia já testada e os efeitos potencialmente desconhecidos de fármaco que sequer adentrou a fase de testes em seres humanos.

71 GIANETTTI, Eduardo. Auto-engano. São Paulo: Companhia das Letras, 2005. p. 33-34.

72 GIANETTTI, Eduardo. Auto-engano. São Paulo: Companhia das Letras, 2005. p. 67-69.

73 A correta indicação do sentido descritivo dos termos avaliatórios permite o controle crítico das práticas do tribunal. FREITAS FILHO, Roberto. Intervenção judicial nos contratos e aplicação dos princípios e das cláusulas gerais: o caso do leasing. Porto Alegre: Sergio Antônio Fabris Editor, 2009. p. 315.
} 
perenes em relação à compra de insumos básicos e manutenção periódica de máquinas e equipamentos. Assim, parece correto concluir que o argumento da reserva do possível, na forma como é atualmente utilizado no debate judicial, é uma falácia de proporções homéricas, já que não se demonstra a efetiva inexistência de recursos, mas apenas a carência de recursos levada a termo por uma gestão inepta e ineficiente.

E, subjacente ao argumento da reserva do possível, há outro autoengano entronizado no debate, qual seja a desorganização orçamentária eventualmente causada pela intervenção judicial na política pública. No particular, veja-se que, apenas no dia 30/12/2014, foram publicadas 12 normas alterando a Lei de Orçamento do ano de 2014 para formalizar créditos especiais ou suplementares no valor total de R \$ 1,5 bilhão. Ora, se, em um único dia, o orçamento pode ser alterado em $\mathrm{R} \$ 1,5$ bilhão para atender os acordos políticos do momento, não parece razoável supor que o cumprimento de ordens judiciais poderia desorganizar aquele orçamento. Afinal, apenas é possível desorganizar algo previamente organizado — o que certamente não parece ser o caso do orçamento brasileiro.

Assim, no aqui e agora do empírico, parece que restam duas alternativas para o Judiciário: a) declara-se incompetente para adentrar no detalhamento das contas públicas e revê o ideário neoconstitucional brasileiro; ou b) assume a responsabilidade integral que permeia o debate sobre a judicialização da política, e passa a analisar o tema de forma abrangente, enfrentando as dimensões e argumentos políticos, gerenciais, orçamentários e financeiros envolvidos, inclusive assumindo sua parcela de responsabilidade pela legítima invasão na gestão pública. Sendo verdade que "o pessimista se queixa do vento, o otimista espera que ele mude, e o realista ajusta as velas" "74, agora é importante entender que o argumento orçamentário exige uma nova postura do Judiciário, um ajuste de velas na jurisprudência que trata de políticas públicas ${ }^{75}$.

\section{Considerações finais}

Este trabalho tentou defender a tese de que há um aspecto voluntarista na adoção de critérios para a formulação do orçamento público, baseado em um uma visão anacrônica do orçamento enquanto mero registro de movimentações patrimoniais, o que dificulta uma abordagem mais técnica para a efetiva estipulação de receitas e despesas. Ademais, para além da real complexidade de construir cenários econômicos que sirvam de estrutura para a formulação do orçamento público, parece razoável afirmar que as premissas utilizadas na estimação da receita pública, porquanto mais voluntárias do que técnicas, mais parecem uma manipulação de expectativas (para o atingimento de critérios formais relativos ao equilíbrio orçamentário) do que uma análise realista sobre as possibilidades factíveis de apropriação, pelo estado, de recursos produzidos no contexto econômico. A hipótese supõe que, do voluntarismo orçamentário, resulta um orçamento mais poético do que técnico, o que culmina em uma postura financeira perdulária do Estado, por sequer definir as receitas e despesas de forma adequada e verossímil. Nesse contexto, parece adequada a alegoria do BMW: um devedor qualquer pode negar o cumprimento de obrigações fundamentais pelo argumento de que faltariam recursos, especialmente na realidade de custeio integral de luxos e volúpias?

Superado o diagnóstico do problema, supõe-se que a solução do problema, do ponto de vista administrativo, envolve o reconhecimento do enfoque gerencial do orçamento, entendido aqui como um sistema necessário para a produção de informações que suportem a tomada de decisão. Na perspectiva do Direito, entretanto, a questão é bem mais complexa, já que envolve a existência de uma distorção no argumento

\footnotetext{
FERRER, Florência. Gestão pública eficiente: impactos econômicos de governos inovadores. Rio de Janeiro: Elsevier, 2007. p. 2.

75 "As decisões sobre a alocação de recursos comuns devem ser compreendidas na dimensão de regras que têm impacto coletivo e que, portanto, devem ser passíveis de sentido coletivo, em um duplo viés, o da adesão e o das consequências. É nesse ponto que a noção de regra encontra a de isonomia, conceito relativo à justiça, núcleo significativo do próprio direito." LIRA, Daiane Nogueira et al. Políticas públicas e protagonismo judicial no STF: relatório de pesquisa do grupo de estudo e pesquisa em políticas públicas e hermenêutica. Revista Universitas JUS. Brasilia, v. 22, n. 2, p. 105-196, jul./dez. 2011. p. 128.
} 
jurídico sobre a reserva do possível, na medida em que postula a existência de um limite material de gastos sem demonstrar a estrutura de gastos que consome os recursos. Nesse contexto, a reserva do possível perfaz argumento superficial e simplório, inclusive após análise e decisão judicial, e formaliza uma jurisprudência também superficial, pois não enfrenta o problema de fundo - a estrutura de receitas e despesas no orçamento. De toda sorte, o objetivo deste trabalho não é defender ou acusar a atuação do Judiciário em questões orçamentárias e de políticas públicas. Não se trata de negar a intervenção judicial, nem de afirmar que o limite orçamentário pode ser desconsiderado pela decisão judicial. Trata-se, na essência, de um alerta para o Poder Judiciário — que antes de negar ou conceder direitos com base no argumento do limite orçamentário precisa melhor investigar qual é o limite orçamentário.

Ao que parece, apenas falta dinheiro nas áreas em que o administrador não tem o interesse de investir, o que evidencia a enorme fragilidade do argumento de que a questão orçamentária é relevante no tema da invasão judicial nas políticas públicas. De fato, parece que a experiência brasileira trata o orçamento de forma despudorada, e o argumento orçamentário é mero subterfúgio para manter essa hegemonia no exercício do despudor - evitando que novos atores também figurem como protagonistas na peça teatral que atualmente se apresenta como gestão pública.

\section{Referências}

ABREU, Luiz Eduardo. A troca das palavras e a troca das coisas: política e linguagem no Congresso Nacional. Revista Mana, Rio de Janeiro, v. 11, n. 2, 2005.

AGUIAR, Afonso Gomes. Direito financeiro: a lei 4.320 - comentada ao alcance de todos. 3. ed. Belo Horizonte: Fórum, 2008.

BARROSO, Luís Roberto. Curso de direito constitucional contemporâneo: os conceitos fundamentais e a construção do novo modelo. 5. ed. São Paulo: Saraiva, 2015.

BONAVIDES, Paulo. Reflexões: política e direito. 2. ed. Rio de Janeiro: Forense, 1978.

BUCCI, Maria Paula Dallari. Controle judicial de políticas públicas: possibilidades e limites. Fórum Administrativo - Dir. Público - FA, Belo Horizonte, ano 9, n. 103, 2009.

CONTI, José Maurício; SCAFF, Fernando Facury (coord.). Orçamentos públicos e direito financeiro. São Paulo: Revista dos Tribunais, 2011.

COOTER, Robert; ULEN, Thomas. Direito e economia. 5. ed. Porto Alegre: Bookman, 2010.

FAORO, Raimundo. Os donos do poder. 5. ed. São Paulo: Globo, 2012.

FERRER, Florência. Gestão pública eficiente: impactos econômicos de governos inovadores. Rio de Janeiro: Elsevier, 2007.

FREITAS FILHO, Roberto. Estudos Jurídicos Críticos (CLS) e coerência das decisões. Revista de Informação Legislativa, Brasília, a. 44, n. 175 jul./set. 2010.

FREITAS FILHO, Roberto. Intervenção judicial nos contratos e aplicação dos princípios e das cláusulas gerais: o caso do leasing. Porto Alegre: Sergio Antonio Fabris Editor, 2010.

GIANETTTI, Eduardo. Auto-engano. São Paulo: Companhia das Letras, 2005.

GRAU, Eros. Por que tenho medo dos juizes. 6. ed. São Paulo: Malheiros, 2014.

HOLANDA, Sérgio Buarque de. Raíres do Brasil. 26. ed. São Paulo: Companhia das Letras, 1995.

KELSEN, Hans. Teoria pura do direito. 8. ed. São Paulo: Martins Fontes, 2014. 
KUHN, Thomas S. A estrutura das revoluções cientificas. 12. ed. São Paulo: Perspectiva, 2013.

KOHAMA, Hélio. Contabilidade pública: teoria e prática. 11. ed. São Paulo: Atlas, 2010.

LIRA, Daiane Nogueira et al. Políticas públicas e protagonismo judicial no STF: relatório de pesquisa do grupo de estudo e pesquisa em políticas públicas e hermenêutica. Revista Universitas JUS, Brasília, v. 22, n. 2, p. 105-196, jul./dez. 2011.

LOPES, José Reinaldo de Lima. Decidindo sobre recursos escassos: raciocínio jurídico e economia. In: Direitos sociais: teoria e prática. São Paulo: Método, 2006.

LUHMANN, Niklas. Sociologia do direito I. Rio de Janeiro: Edições Tempo Brasileiro, 1983.

MCGREGOOR, Evan; BOORMAN, Charles. Long way down. London: Hachette Digital, 2007.

MATIAS-PEREIRA, José. Curso de Administração Pública: foco nas instituições e ações governamentais. 2. ed. São Paulo: Atlas, 2009.

MENDES, Gilmar Ferreira; BRANCO, Paulo Gustavo Gonet. Curso de direito constitucional. 6. ed. São Paulo: Saraiva, 2015.

MILLS, C. Wright; GERTH, H. H. Max Weber: ensaios de sociologia. Rio de Janeiro: Zahar, 1974.

PAUlA, Ana Paula Paes de. Por uma nova gestão pública: limites e potencialidades da experiência contemporânea. Rio de Janeiro: Editora FGV, 2005.

PETERS, Tom. Prosperando no caos. São Paulo: Harbra, 1989.

POPPER, Karl. O mito do contexto: em defesa da ciência e da racionalidade. Lisboa: Edições 70, 1996.

RODRIGUEZ, José Rodrigo. Como decidem as cortes? Para uma crítica do Direito (Brasileiro). Rio de Janeiro: FGV, 2013.

SGARBOSSA, Luís Fernando. Teoria da derrotabilidade: pressupostos teóricos e aplicações. Curitiba: Juruá, 2012.

SILVA, Lino Martins. Contabilidade governamental: um enfoque administrativo da nova contabilidade pública. 8. ed. São Paulo: Atlas, 2009.

VIEIRA, Oscar Vilhena. Supremocracia. Revista Direito GV, n. 8, 2008.

WANG, Daniel Wei Liang. Escassez de recursos, custos dos direitos e reserva do possível na jurisprudência do STF. Revista Direito GV, São Paulo, jul./dez. 2008. 
Para publicar na revista Brasileira de Políticas Públicas, acesse o endereço eletrônico www.rbpp.uniceub.br

Observe as normas de publicação, para facilitar e agilizar o trabalho de edição. 